\title{
Hygienical Survey on Seasoned Ricotta Produced in Alpine Dairies in Northern-Italy with Focus on Pink Discoloration due to Serratia Spp.
}

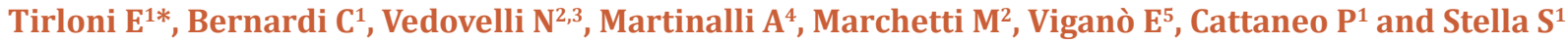 \\ ${ }^{1}$ Department of Health, Animal Science and Food Safety, University of Milan, Italy \\ ${ }^{2}$ Agenzie per la Tutela della Salute della Montagna, Italy \\ ${ }^{3}$ Agenzie per la Tutela della Salute Milano Città Metropolitana, Italy \\ ${ }^{4}$ Freelance, Italy \\ ${ }^{5}$ Tecnozoosrl, Torreselle di Piombino Dese, Italy
}

Submission: October 19, 2017; Published: November 29, 2017

*Corresponding author: Tirloni E, University of Milan, Department of Health, Animal Science and Food Safety, Via Celoria 10, 20133, Milan, Italy, Tel: 00390250317855; Email: erica.tirloni@unimi.it

\begin{abstract}
This study stems from the need to clarify the onset of pink discoloration on seasoned crust ricotta, produced in a dairy farm in the valley bottom of Val Gerola (Valtellina, Sondrio) in particular during the summer season. The isolation and the identification of the colonies from the spoiled product showed the presence of Serratia spp. A first environmental sampling on cheese making and seasoning facilities and molds, conducted in the dairy farm involved, showed the presence of Serratia spp. also on the board of the cold storage cell and in the refrigerator. In a second stage, environmental samplings were conducted in nine dairies producing seasoned ricotta, with the aim to highlight the presence of Listeria monocytogenes, Salmonella spp., Escherichia coli, Enterobacteriaceae, VTEC and Serratia spp. Results obtained showed absence of VTEC and Salmonella spp. In only one dairy L. monocytogenes was found on a wooden board and a wooden mold. Higher presence of E. coli and Enterobacteriaceae was found on products, on utensils and in facilities in all the diaries. Afterwards, growth abilities of Serratia spp, isolated from the color pink episode, were investigated, showing ability to grow between 4 and $37^{\circ} \mathrm{C}$ in broth and on media. Finally, a simulation of the appearance of the defect was performed inoculating Serratia spp in ricottas laid down on wooden boards and maintained at 4,8 and $15^{\circ} \mathrm{C}$, but no discoloration was recorded, perhaps due to the different condition in the thermostats if compared to the seasoning cells in the dairy.
\end{abstract}

Keywords: Seasoned ricotta; Serratia spp; Listeria monocytogenes; Salmonella spp; Verocytotoxin-producing Escherichia coli (VTEC); Escherichia coli; Enterobacteriaceae; Alpine dairies

\section{Introduction}

Traditional foods, like alpine dairy products, are of particular impact for the areas where they are produced. Typical products are complex matrixes that are characterized by special and peculiar sensorial features associated to several factors like animal feeding, technology of production, cheese manufacturing practices and ripening conditions but they are also important in terms of sustainability of the micro-economy that they create in the production territory. These aspects match perfectly with the recent consumers' trend to consume " $0 \mathrm{~km}$ " and artisanal dairy products as they are considered more tasty, healthy and generally fresh.

Topic of the present study is seasoned ricotta, a dairy product based on the use of whey resulting from cheese manufacture (mainly Bitto PDO cheese), produced in Val Gerola, in the Valtellina area, in the alpine Lombardy area; the production of seasoned ricotta briefly consists on whey heating up to $60-70{ }^{\circ} \mathrm{C}$, then ingredients are added (generally salt, milk cream and raw milk). Afterwards, acidification occurs thanks to the addition of food grade organic acids (mainly citric). Subsequently, heating continues up to $90{ }^{\circ} \mathrm{C}$ and whey protein coagulation occurs. Ricotta is then collected in molds in order to allow the drain. Finally, the product is maintained in cold storage rooms and sold after a variable ripening time (from few days up to several months) depending on sales demand.

Traditionally, alpine dairies where seasoned ricotta is produced, are located close to farmers home, to the cattle-stalls 
and the pasture while the dairies located in the valley bottom, are placed nearby the farm. They are small family businesses with one or two people involved and where, if needed, other family components take part to the activities. The structures involved in the production of this dairy product, like for many mountain cheeses, sometimes present weaknesses not only due to structural shortcomings but also to cleaning procedures and working practices, as already stated in previous studies [1,2].

The early stages of the present study have sprung up on a referral by a manufacturer producing seasoned ricotta located in the valley bottom in Valtellina who found some ricotta products, at different seasoning stages, characterized by a pink discoloration on the crust surface. This color alteration is a sporadic but persistent defect in a wide range of ripened cheese varieties (Swiss, Cheddar, PDO Grana, and Italian types). A large variety of pigments could be produced by several bacteria and fungi and might be recognized as responsible for discoloration of dairy products [3]. As reported by Daly et al. [4], some spoilage microorganisms (Pseudomonas spp, Enterococci, Serratia spp.) but also starter cultures have been associated to pink/red discolorations in cheese [5-8]; this discoloration was already reported also in Italian seasoned ricotta [9].

In the present study, a survey on the main dairies producing seasoned ricotta and located in Valtellina, was conducted with the aim to evaluate if the pink discoloration defect was detected. If present, an investigation on the onset was finalized. Different typologies of dairies were taken in consideration: seven in alpine territory and two in the valley bottom. Moreover, in order to evaluate the hygiene of working conditions, the prevalence of Listeria monocytogenes, Salmonella spp., generic Escherichia coli and Verocytotoxin-producing Escherichia coli (VTEC) were also considered. Finally a description of temperature of growth of isolates from seasoned ricotta samples with pink/red discoloration was conducted, with the aim to characterize their potentiality in the production process.

\section{Materials and Methods}

\section{Case history}

After a referral by a manufacturer (I) of a pink discoloration on the crust surface of seasoned ricotta who found some products with at different seasoning stages, three of them were analyzed
(Figure 1). Superficial samplings were made by sterile loops, with the aim to isolate the colonies responsible for this colour alteration. The isolates were streaked onto Tryptic Soy Agar (Biogenetics, Ponte San Niccolò, PD) and Mascarpone Cheese Agar (Mascarpone cheese 1000g/L, NaCl 10g/L, Yeast Extract 6g/L, Agar Agar 15g/L). Four isolates were randomly selected from the plates and after purification; colonies were subjected to Gram staining and to catalase test. Colonies were identified by PCR as described previously by Rudi et al. [10].

Contextually the sampling of the spoiled products, an environmental sampling was conducted with the aim to identify the source of contamination in the locals of production of the dairy where the defect was found, and if the microorganism responsible of the pink color alteration was present. Surface samplings were performed using sterile swabs in the dairy and included the sampling points as reported in (Table 1\&2). For the detection of bacteria responsible for pink discoloration, $25 \mathrm{~g}$ of solid sample were homogenized and enriched in 225-mL Tryptic Soy Broth (Biogenetics), while swab samples were included in $10 \mathrm{~mL}$ tubes of the same broth. After incubation for $24 \mathrm{~h}$ at $37^{\circ} \mathrm{C}$, $0.1 \mathrm{~mL}$ of the enrichment was transferred on Mascarpone Agar and incubated for $24 \mathrm{~h}$ at $37^{\circ} \mathrm{C}$. If present, typical pink colonies were isolated.

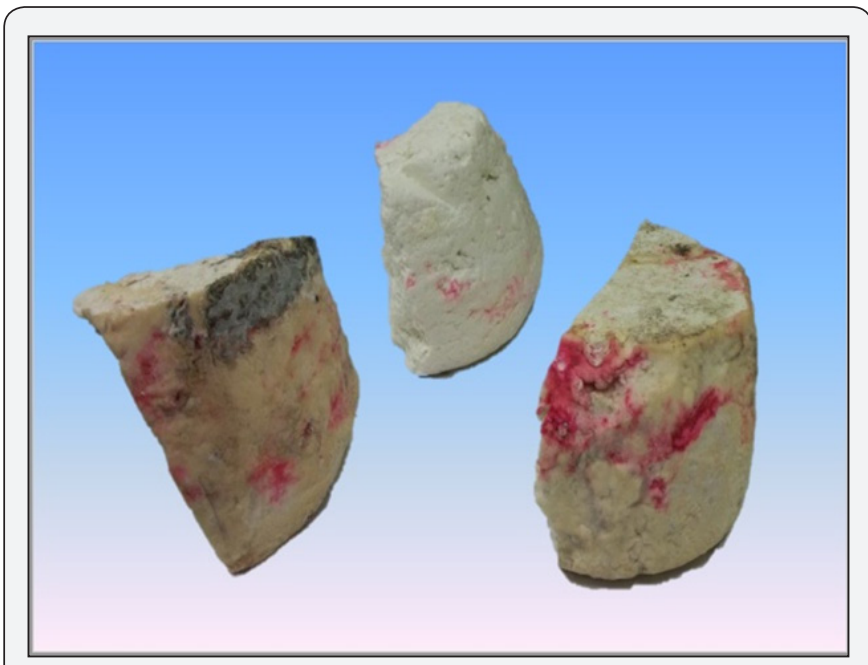

Figure 1: Pink discolouration of ricotta cheese at different seasoning stage.

Table 1: Escherichia coli prevalence.

\begin{tabular}{|c|c|c|c|c|c|c|c|c|c|c|c|c|c|}
\hline Category & Dairy & A & B & C & D & $\mathbf{E}$ & $\mathbf{F}$ & G & $\mathbf{H}$ & I & $\begin{array}{c}\text { Total } \\
\text { positivity } \\
\text { for } E \text {. coli }\end{array}$ & $\begin{array}{c}\% \\
\text { Positivity }\end{array}$ & $\begin{array}{c}\% \\
\text { Positivity } \\
\text { for } \\
\text { category }\end{array}$ \\
\hline \multirow{4}{*}{ Ingredients } & Rennet & - & - & - & - & - & + & - & - & - & $1 / 9$ & $11 \%$ & \multirow{4}{*}{$7 \%$} \\
\hline & Lactic acid & - & - & - & - & - & - & - & - & - & $0 / 9$ & $0 \%$ & \\
\hline & Salt & - & - & & - & - & - & - & - & - & $0 / 8$ & $0 \%$ & \\
\hline & Starter cultures & & & & & & + & - & - & - & $1 / 4$ & $25 \%$ & \\
\hline
\end{tabular}




\begin{tabular}{|c|c|c|c|c|c|c|c|c|c|c|c|c|c|}
\hline \multirow{2}{*}{$\begin{array}{l}\text { Milk } \\
\text { facilities }\end{array}$} & Wall bunk tank & & & + & - & - & - & & - & - & $1 / 6$ & $16 \%$ & \multirow{2}{*}{$46 \%$} \\
\hline & Plastic bucket & & & + & + & - & - & + & + & + & $5 / 7$ & $71 \%$ & \\
\hline \multirow{5}{*}{$\begin{array}{l}\text { Milk boiler } \\
\text { facilities }\end{array}$} & Stick wood boiler & - & - & - & - & & - & - & & - & $0 / 7$ & $0 \%$ & \multirow{5}{*}{$0 \%$} \\
\hline & Boiler thermometer & - & - & - & - & - & - & - & - & - & $0 / 9$ & $0 \%$ & \\
\hline & Mixing copper boiler 1 & - & - & - & - & - & & & - & & $0 / 12$ & $0 \%$ & \\
\hline & Mixing copper boiler 2 & - & - & - & & & - & - & & - & & & \\
\hline & Thorn curd & - & - & - & - & - & - & - & - & - & $0 / 9$ & $0 \%$ & \\
\hline \multirow{6}{*}{$\begin{array}{l}\text { Cheese } \\
\text { molds }\end{array}$} & $\begin{array}{l}\text { Trolley where molds are } \\
\text { positioned }\end{array}$ & + & + & + & & - & + & + & + & - & $6 / 8$ & $75 \%$ & \multirow{6}{*}{$50 \%$} \\
\hline & Plastic molds & - & + & & & & - & - & - & - & $3 / 5$ & $17 \%$ & \\
\hline & Extern wooden molds & + & - & & & + & & - & & + & $3 / 5$ & $60 \%$ & \\
\hline & Intern wooden molds & - & + & & & - & + & - & & & $2 / 5$ & $40 \%$ & \\
\hline & Wooden molds 1 & - & + & + & - & - & - & & & & $6 / 12$ & $50 \%$ & \\
\hline & Wooden molds 2 & + & + & - & + & + & - & & & & & & \\
\hline \multirow{3}{*}{$\begin{array}{l}\text { Fresh } \\
\text { ricotta }\end{array}$} & Fresh ricotta in mold 1 & - & + & + & - & - & & - & + & & $5 / 13$ & $38 \%$ & \multirow{3}{*}{$40 \%$} \\
\hline & Fresh ricotta in mold 2 & - & + & - & - & - & & & + & & & & \\
\hline & Fresh ricotta & - & + & & & & & & & & $1 / 2$ & $50 \%$ & \\
\hline \multirow{3}{*}{$\begin{array}{l}\text { Seasoning } \\
\text { facilities }\end{array}$} & $\begin{array}{l}\text { Board in the storage cold cell } \\
\text { (wet) }\end{array}$ & - & - & & - & - & - & & - & + & $1 / 7$ & $14 \%$ & \multirow{2}{*}{$11 \%$} \\
\hline & $\begin{array}{l}\text { Board in the storage cold cell } \\
\text { (dry) }\end{array}$ & + & - & & - & - & - & - & - & - & $1 / 8$ & $13 \%$ & \\
\hline & Seasoning board & - & - & & & & & - & & & $0 / 3$ & $0 \%$ & \multirow{4}{*}{$67 \%$} \\
\hline \multirow{3}{*}{$\begin{array}{l}\text { Seasoned } \\
\text { ricotta }\end{array}$} & Seasoned ricotta 1 & & & & + & & & & + & + & $6 / 7$ & $86 \%$ & \\
\hline & Seasoned ricotta 2 & - & & & + & & & & + & + & & & \\
\hline & Ricotta crust & & - & & & & - & & & & $0 / 2$ & $0 \%$ & \\
\hline \multirow{3}{*}{$\begin{array}{l}\text { Other } \\
\text { products }\end{array}$} & $\begin{array}{l}\text { Fresh cheese in cold storage } \\
\text { cell } 1\end{array}$ & + & & + & + & - & - & + & + & + & $11 / 17$ & $65 \%$ & \multirow{3}{*}{$48 \%$} \\
\hline & $\begin{array}{l}\text { Fresh cheese in cold storage } \\
\text { cell } 2\end{array}$ & - & + & + & - & + & - & - & + & + & & & \\
\hline & $\begin{array}{c}\text { Seasoned cheese in cold storage } \\
\text { cell }\end{array}$ & - & - & & - & + & - & - & - & - & $1 / 8$ & $13 \%$ & \\
\hline \multirow{3}{*}{$\begin{array}{c}\text { Other } \\
\text { samples }\end{array}$} & Brine & & & & & & + & & & & $1 / 1$ & $100 \%$ & \multirow{3}{*}{$20 \%$} \\
\hline & Knife & + & & & + & - & - & - & + & $2 / 7$ & $2 / 7$ & $29 \%$ & \\
\hline & Water & & - & - & - & - & - & & - & - & $0 / 7$ & $0 \%$ & \\
\hline
\end{tabular}

Table 2 : Entero bacteriaceae prevalence.

\begin{tabular}{|c|c|c|c|c|c|c|c|c|c|c|c|c|c|}
\hline Category & Dairy & A & B & C & D & $\mathbf{E}$ & $\mathbf{F}$ & G & $\mathbf{H}$ & I & $\begin{array}{c}\text { Total } \\
\text { positivity } \\
\text { for E. coli }\end{array}$ & $\begin{array}{c}\% \\
\text { Positivity }\end{array}$ & $\begin{array}{c}\% \\
\text { Positivity } \\
\text { for } \\
\text { category }\end{array}$ \\
\hline \multirow{4}{*}{ Ingredients } & Rennet & - & - & - & - & - & + & - & - & - & $1 / 9$ & $11 \%$ & \multirow{4}{*}{$10 \%$} \\
\hline & Lactic acid & - & - & - & - & - & - & - & - & - & $0 / 9$ & $0 \%$ & \\
\hline & Starter cultures & & & & & & + & + & - & - & $2 / 4$ & $50 \%$ & \\
\hline & Salt & - & - & & - & - & - & - & - & - & $0 / 8$ & $0 \%$ & \\
\hline \multirow{2}{*}{ Milk facilities } & Wall bunk tank & & & + & - & + & - & & - & + & $3 / 6$ & $50 \%$ & \multirow{2}{*}{$69 \%$} \\
\hline & Plastic bucket & & & + & + & + & - & + & + & + & $6 / 7$ & $86 \%$ & \\
\hline \multirow{3}{*}{$\begin{array}{l}\text { Milk boiler } \\
\text { facilities }\end{array}$} & Stick wood boiler & - & - & - & + & & - & & - & + & $3 / 7$ & $43 \%$ & \multirow{3}{*}{$38 \%$} \\
\hline & Boiler thermometer & - & - & + & + & + & - & + & + & + & $6 / 9$ & $67 \%$ & \\
\hline & $\begin{array}{c}\text { Mixing copper boiler } \\
1\end{array}$ & - & - & - & + & - & & & - & & $2 / 12$ & $17 \%$ & \\
\hline
\end{tabular}




\begin{tabular}{|c|c|c|c|c|c|c|c|c|c|c|c|c|c|}
\hline & $\begin{array}{l}\text { Mixing copper boiler } \\
2\end{array}$ & - & - & - & & & - & - & & + & & & \\
\hline & Thorn curd & - & - & + & - & - & - & - & + & + & $3 / 9$ & $33 \%$ & \\
\hline \multirow{6}{*}{ Cheese molds } & $\begin{array}{l}\text { Trolley where molds } \\
\text { are positioned }\end{array}$ & + & + & + & & + & + & + & + & + & $8 / 8$ & $100 \%$ & \multirow{6}{*}{$86 \%$} \\
\hline & Plastic molds & - & + & & & & + & + & + & + & $5 / 6$ & $83 \%$ & \\
\hline & $\begin{array}{l}\text { Extern wooden } \\
\text { molds }\end{array}$ & + & - & & & + & & + & & + & $4 / 5$ & $80 \%$ & \\
\hline & Intern wooden molds & - & + & & & + & + & + & & & $4 / 5$ & $80 \%$ & \\
\hline & Wooden molds 1 & - & + & + & + & + & + & & & & $10 / 12$ & $83 \%$ & \\
\hline & Wooden molds 2 & + & + & + & + & + & + & & & & & & \\
\hline \multirow{3}{*}{ Fresh ricotta } & $\begin{array}{l}\text { Fresh ricotta in } \\
\text { mold } 1\end{array}$ & - & + & + & + & - & & + & + & & $9 / 13$ & $69 \%$ & \multirow{3}{*}{$67 \%$} \\
\hline & $\begin{array}{l}\text { Fresh ricotta in } \\
\text { mold } 2\end{array}$ & - & + & + & + & - & & & + & & & & \\
\hline & Fresh ricotta & - & + & & & & & & & & $1 / 2$ & $50 \%$ & \\
\hline \multirow{3}{*}{$\begin{array}{l}\text { Seasoning } \\
\text { facilities }\end{array}$} & $\begin{array}{l}\text { Board in the storage } \\
\text { cold cell (wet) }\end{array}$ & - & - & & + & + & + & & + & + & $5 / 7$ & $71 \%$ & \multirow{3}{*}{$67 \%$} \\
\hline & $\begin{array}{l}\text { Board in the storage } \\
\text { cold cell (dry) }\end{array}$ & + & - & & + & + & + & + & + & - & $6 / 8$ & $75 \%$ & \\
\hline & Seasoning board & - & - & & & & & + & & & $1 / 3$ & $33 \%$ & \\
\hline \multirow{3}{*}{$\begin{array}{l}\text { Seasoned } \\
\text { ricotta }\end{array}$} & Seasoned ricotta 1 & & & & + & & & & + & + & $6 / 7$ & $86 \%$ & \multirow{3}{*}{$78 \%$} \\
\hline & Seasoned ricotta 2 & - & & & + & & & & + & + & & & \\
\hline & Ricotta crust & & - & & & & + & & & & $1 / 2$ & $50 \%$ & \\
\hline \multirow{3}{*}{$\begin{array}{l}\text { Other } \\
\text { products }\end{array}$} & $\begin{array}{l}\text { Fresh cheese in cold } \\
\text { storage cell } 1\end{array}$ & + & & & + & + & + & + & + & + & $16 / 17$ & $94 \%$ & \multirow{3}{*}{$88 \%$} \\
\hline & $\begin{array}{l}\text { Fresh cheese in cold } \\
\text { storage cell } 2\end{array}$ & - & + & + & + & + & + & + & + & + & & & \\
\hline & $\begin{array}{l}\text { Seasoned cheese in } \\
\text { cold storage cell }\end{array}$ & - & - & & + & + & + & + & + & - & $5 / 8$ & $63 \%$ & \\
\hline \multirow{3}{*}{ Other samples } & Brine & & & & & & + & & & & $1 / 1$ & $100 \%$ & \multirow{3}{*}{$60 \%$} \\
\hline & Knife & + & & & + & + & + & + & + & + & $7 / 7$ & $100 \%$ & \\
\hline & Water & & - & - & - & - & - & & + & - & $1 / 7$ & $14 \%$ & \\
\hline
\end{tabular}

Environmental sampling points were divided into different 9 different categories (Table 1): an aliquot of each ingredient and of fresh and seasoned ricotta that were sampled in each of the dairies was aseptically inserted in sterile tubes or bags, while for surface sampling of milk and seasoning facilities and molds, pre-moistened swabs were swabbed on the surfaces and the facilities. The swab was passed over the surface of interest $\left(100 \mathrm{~cm}^{2}\right)$ and rotated to guarantee that the whole surface was sampled. For each product and surface, four swabs were used. All samples were immediately put at refrigerated conditions until processing, and cultured within $12 \mathrm{~h}$.

\section{Experimental plan}

In a second time, a total of 9 dairies were considered for the trial (including the dairy reported in section 2.1), all producing seasoned ricotta (A to I); seven of them (A to G) were located in little alpine dairies placed in Val Gerola, in Valtellina (from 1400 to $1900 \mathrm{~m}$ above sea level)and produced ricotta from bovine and caprine milk (80\%-20\% respectively), produced with whole milk obtained from two daily milking of all the animals (around
50-60 bovines and a variable number of caprine heads). The other two dairies ( $\mathrm{H}$ and I) were situated in the valley bottom in Cosio Valtellina, and produced ricotta from bovine milk obtained from two daily milking. All the dairies procure water from the aqueduct and were characterized by the presence of ultraviolet sterilizers. Diaries were mainly composed by two rooms: one where cheese making occurs and one where seasoning occurred.

Environmental sampling: Surface samplings were performed in all the dairies in two different sampling sessions (August for alpine dairies, October for valley bottom dairies) and included the sampling points as reported in Table 1. Sampling procedures were conducted.

Microbiological parameters searched: In this sampling session, for each sampling point the presence of Listeria monocytogenes, of Salmonella spp., E. coli, VTEC and bacteria responsible for pink discolouration was performed.

For the detection of $L$. monocytogenes, $25 \mathrm{~g}$ of solid sample were homogenized and enriched in 225-mL Half-Fraser Broth (Biogenetics, Ponte San Niccolò, PD), while swab samples were 
included in $10 \mathrm{~mL}$ tubes of the same broth. After incubation for $24 \mathrm{~h}$ at $37{ }^{\circ} \mathrm{C}, 0.1 \mathrm{~mL}$ of the enrichment was transferred on Palcam Agar and incubated for $24 \mathrm{~h}$ at $37^{\circ} \mathrm{C}$. Suspected colonies were isolated on Rapid L'mono and eventually confirmed the identification with Gram stain determination, catalase and oxidase reactions and using a biochemical test MID 67 (Biogenetics). In parallel the SureTect ${ }^{\circledR}$ Listeria monocytogenes species PCR Assay, a validated multiplex real-time assay that incorporates unique primer and probe components for highlyspecific detection, was used in accordance with the appropriate validated protocol.

For the detection of Salmonella spp., $25 \mathrm{~g}$ of solid sample were homogenized and enriched in 225-mL Buffered Peptone Water (Biogenetics), while swab samples were included in $10 \mathrm{~mL}$ tubes of the same broth. After incubation for $24 \mathrm{~h}$ at 37 ${ }^{\circ} \mathrm{C}, 0.1 \mathrm{~mL}$ of the pre-enrichment broth was transferred on Harlequin Salmonella ABC (Biogenetics) and incubated for $24 \mathrm{~h}$ at $37{ }^{\circ} \mathrm{C}$. Suspected colonies were isolated and confirmed by Gram stain determination, catalase and oxidize reactions and using a biochemical test API (Biogenetics). In parallel the Sure Tect $®$ Salmonella spp. species PCR Assay, was performed in accordance with the appropriate validated protocol.

For the detection of Enterobacteriaceae, generic Escherichia coli and VTEC, $25 \mathrm{~g}$ of solid sample were homogenized and enriched in 225-mL Buffered Peptone Water (Biogenetics), while swab samples were included in $10 \mathrm{~mL}$ tubes of the same broth. After incubation for $24 \mathrm{~h}$ at $37^{\circ} \mathrm{C}, 0.1 \mathrm{~mL}$ of the enrichment was transferred on VRBG (Biogenetics) for the detection of Enterobacteriaceae, TBX (Biogenetics) for generic E. coli and Harlequin SMAC-BCIG (Biogenetics) for the detection of VTEC and incubated for $24 \mathrm{~h}$ at $37^{\circ} \mathrm{C}$. Suspected colonies on Harlequin SMAC-BCIG were isolated and confirmed by PCR. In parallel the Sure Tect ${ }^{\circledR}$ VTEC Escherichia coli 0157species PCR Assay was performed.

Finally for the detection of bacteria responsible for pink discoloration, 25g of solid sample were homogenized and enriched in 225-mL Tryptic Soy Broth (Biogenetics), while swab samples were included in $10 \mathrm{~mL}$ tubes of the same broth. After incubation for $24 \mathrm{~h}$ at $37{ }^{\circ} \mathrm{C}, 0.1 \mathrm{~mL}$ of the enrichment were transferred on Mascarpone Agar and incubated for $24 \mathrm{~h}$ at $37^{\circ} \mathrm{C}$. If present, typical pink colonies were isolated and submitted to PCR identification, as previously described.

\section{Growth range of isolates responsible of pink discolouration of ricotta}

The strain stocks of the isolates responsible for pink discoloration after identification were kept frozen at $-80{ }^{\circ} \mathrm{C}$ in Microbank Cryogenic vials (Pro-Lab Diagnostics U.K., Merseyside, UK). A loop of the bacterial stock culture was transferred into TSB and incubated at $37{ }^{\circ} \mathrm{C}$ for $24 \mathrm{~h}$. Cell concentration of the strain suspension was assessed by counting under a contrast phase microscopy (BA 310, Motic, Barcelona, and E) with a final starting desired concentration of 2 Log CFUml-1. Replicate tubes of the mixture were prepared in order to carry out growth experiments at constant temperatures $\left(4^{\circ} \mathrm{C}, 8^{\circ} \mathrm{C}, 15^{\circ} \mathrm{C}, 20^{\circ} \mathrm{C}\right.$, $37^{\circ} \mathrm{C}, 42^{\circ} \mathrm{C}$ and $44^{\circ} \mathrm{C}$ ). Growth curves were generating by using $540 \mathrm{~nm}$ absorbance measurements (6320D spectrophotometer, Jenway, Staffordshire, UK). At settled times (0, 18, 24, 42, 49, 68, $74,95,139,163,211,242,261,296$ and 319h), absorbance was recorded at each temperature of incubation. The mixture was also plated in duplicate onto Mascarpone Agar plates and incubated at the same different temperatures. Plates were monitored for colony formation twice per day for up to $311 \mathrm{~h}$ (13 days).

\section{Inoculation of ricotta}

A loop of the strain stocks of the isolates kept frozen at $-80^{\circ} \mathrm{C}$ was transferred into TSB and incubated at $37{ }^{\circ} \mathrm{C}$ for $24 \mathrm{~h}$. Cell concentration of the strain suspension was assessed by counting under a contrast phase microscopy (BA 310, Motic, Barcelona, and E) with a final starting desired concentration of 2 Log CFU $\mathrm{ml}-1$. The suspension was inoculated in duplicate on the surface of $50 \mathrm{~g}$ samples of ricotta produced $24 \mathrm{~h}$ before in one of the seven alpine dairies and incubated at $4{ }^{\circ} \mathrm{C}, 8{ }^{\circ} \mathrm{C}, 15^{\circ} \mathrm{C}, 20^{\circ} \mathrm{C}$ and $37{ }^{\circ} \mathrm{C}$. A series of non-inoculated (blank) ricotta samples was also incubated at the same conditions. At settled times $(0,6,21$, $26,31,45,50,55,70,80,94,121,167,189,215,239,263,287$, 335 and $359 \mathrm{~h}$ ), ricotta samples were visually checked in order to identify the appearance of the pink discoloration. At each time, blank samples were submitted to $\mathrm{pH}$ measurement (Amel Instrument, 334-B, Milan, I) and aw determination (Hygrolab Rotronic).

\section{Results and Discussion}

\section{Identification of strains responsible for pink discolouration and environmental sampling (part 1)}

This study originates from the need expressed by a dairy producer to understand the causes of the appearance of pink discoloration on the crusts of seasoned ricotta; this discoloration episodes were frequently reported by many other dairy producers, especially in the mountain pastures in the alpine area of Val Gerola and in particular during the summer season. The identification of the isolates from the spoiled product allows identifying that the microorganisms responsible of the defect were Serratia spp.; in recent years, Serratia spp. has been studied for its ability to produce lipase. This gram negative microorganism, showed the ability to form prodigiosin, accountable to confer the unique characteristic red/pink color. The favored ecological niches of Serratia spp. are water and the plants, but this microorganism is also responsible for the contamination of food. In recent years, Serratia marcescens was already found to be responsible for pink discoloration in seasoned ricotta from Italy.

The environmental sampling conducted in the same dairy allowed to detect Serratia spp. also on the board of the cold storage cell (both moist and dry) and in the refrigerator. Moreover positive samples resulted to be the knife and the chopping board and dairy products in a storage cell. All the 5 
positive samples were found on surfaces or utensils that come in contact with the final product (seasoned ricotta) cyclically and that were not subjected to the daily procedures of cleaning and disinfection. The absence of contamination by Serratia spp. in some working surfaces mean how the correct application of the Sanitation Standard Operating Procedures (SSOP) were sufficient for preventing the presence of these bacteria from the surfaces.

\section{Environmental sampling (part 2)}

In a second time, another environmental sampling was conducted considering a total of 9 dairies producing seasoned ricotta in Valtellina. At this stage not only Serratia spp. was researched but also other spoilage microorganisms (Enterobacteriaceae, generic E. coli) and the main potential pathogenic bacteria (L. monocytogenes, Salmonella spp. and VTEC), with the purpose to highlight the level of hygienically standards of these productive realties and evaluating if consumer can consider reasonably and fairly safe from a microbiological point of view the dairy products manufactured in these diaries.

None of the sample from all the dairies involved resulted to be positive for Salmonella spp. and VTEC, food borne pathogens that naturally populate the ruminant intestinal tract; as a matter of fact, dairy farms are one of the major sources of these bacteria. The results obtained underlined that all the strategies put in place for the control of the presence of these pathogens in dairy farm and in cheese making rooms were properly made, in particular the monitoring and when possible the avoid of the administration of contaminated animal drinking water and feed, a correct managing of faecal excreta and the accurate management of new-born; all these actions likely allowed to reduce the persistence of these bacteria in the animals and to prevent the generation of new reservoirs in the dairy environment [11]. Our findings should be positively considered as several previous studies evaluated the survival of these microorganisms during the production and ripening of various cheeses, demonstrating their ability to persist during the cheese making process and to survive after production for long times, especially when raw milk was used during production [12-14].

Listeria monocytogenes is also frequently associated with dairy farm environments contamination with ruminants that play an important role in its maintenance [15]. Considering the dairy industries evaluated in the present study, L. monocytogenes, was present (results confirmed also with real time PCR) in few environmental samples, all belonging to the dairy "E", located in alpine site, which resulted positive for the wooden board used for ripening and the wooden mold. Wooden utensils are traditionally used in these productions although they represent a key risk factors as accurate and frequent cleaning and sanitization are required as they are characterized by porosity and high humidity thus they better support microbial proliferation if compared to steel ones; it is very frequent that wooden utensils are cleaned just with boiling water or the residual from the cheese making ("scotta"), especially in alpine dairies, while they should require more attention during the cleaning procedures. In any case, none of the ricotta samples resulted positive for the presence of the pathogen. In fact, the regular maintenance of good hygienically standards is needed in cheese production in order to minimize L. monocytogenes presence, especially considering its ability to stick to food and non-food surfaces. Finally of particular concern should be considered L. mono cytogenes ability to play out a series of mechanisms (e.g. take part to bio film formation), that facilitate its persistence in dairy processing plants and its potential to be spread onto the end product where it can be vital during its shelf-life $[16,17]$. Eradication of this pathogen from dairy plant is not easy, especially for dairies set in isolated zones, such as those in alpine areas, where it is hard to maintain good hygienically standards.

The prevalence of generic E. coli and Enterobacteriaceae (Table 1\&2), important faecal contamination indicators, showed elevate positive rates. In particular, Enterobacteriaceae were found in extremely high rates especially in cheese molds, with $100 \%$ of positivity found in trolley where molds are positioned when draining and in seasoned ricotta and other dairy products analyzed. Also E. coli presence was widespread on the products and cheese molds, while lower percentage were found in ingredients and milk boiler facilities.

High positivity rates of these two parameters found on utensils and facilities, could be due to a possible contamination that comes from outside: all the dairies involved in this study did not have a filter zone before the entrance in the cheese making locals; the absence of a water distribution point for washing the boots or the absence of a barrier (gate side) with a sanitation obliged point could explain the presence of these contaminants on almost all the surfaces and utensils, in almost all the nine dairies. In the diaries considered, almost all the cheese making workers declared to be also involved in milking and animal feeding and very often $t$ use the same boots used also in the locals dedicated to the cheese making with inevitable transition from dirty to clean areas and consequent dragging of bacteria and unclean material.

Moreover, many dairies do not have a sales area located outside the cheese making locals, thus products are directly sold in processing rooms, with the desultory possibility of the permanence of external people also during the production stages, incrementing the number of other sources of contamination.

Considering the E. coli and Enterobacteriaceae rates related to the final products (seasoned ricotta but also other products produced in the dairies), it is possible that improper cleaning operations and poor hygiene behaviors of workers facilitated the transfer of microorganisms to the final products. In this light also the quality and the correct administration of raw materials should be considered (e.g. starter cultures resulted for $25 \%$ and $50 \%$ positive for E. coli and Enterobacteriaceae, respectively), with cross contamination likely occurring due to inadequate hygienic habits put in place by operators. 
In none of the samples from the dairies was found Serratia spp., although all the producers revealed that color defect episodes occurred previously, mainly in the summer season. Also pink color discoloration was not found during the sampling session. Serratia spp. is a secondary contamination microorganism that is likely to occur whenever good hygiene practices are ignored or not completely applied: during production especially in alpine diaries, the application of correct cleaning and sanitization procedures and the right management of the final products, is difficult, in particular in summer season where the environmental conditions has a strong influence especially on seasoning (especially when present high environmental moisture or abundant rain). From this study it was not possible to identify which were the sources for the superficial contamination of ricotta by Serratia spp. but important thermal characteristics of growth were identified.

\section{Growth of Serratia spp. in vitro and on ricotta}

The strain of Serratia spp. causing the color pink discoloration of seasoned ricotta samples (Table 3 ) was found to grow between 4 and $37^{\circ} \mathrm{C}$ in broth and also on Mascarpone Agar; at 41 and $44^{\circ} \mathrm{C}$ the microorganism resulted not to be able to grow, confirming to be a non-thermophilic bacterium. At $37{ }^{\circ} \mathrm{C}$ the growth was very fast in broth and on the solid medium. At 15 and $20{ }^{\circ} \mathrm{C}$ growth occurred within 24 and $42 \mathrm{~h}$ : this temperature range can be likely found during alp seasoning. At 4 and $8{ }^{\circ} \mathrm{C}$ growth was observed within 10 days. These data confirmed the psychrotrophic ability of the strain to grow at temperatures that can be easily reached during seasoning and storage.

Table 3: Growth thermal ability of Serratia spp. in broth and mascarpone agar cheese

\begin{tabular}{|c|c|c|c|c|c|c|c|c|c|c|c|c|c|c|c|}
\hline \multirow{8}{*}{ Serratia spp. Broth } & $\mathbf{h}$ & 18 & 24 & 42 & 49 & 68 & 74 & 95 & 139 & 163 & 211 & 242 & 261 & 296 & 319 \\
\hline & $4{ }^{\circ} \mathrm{C}$ & - & - & - & - & - & - & - & - & - & - & $+/-$ & + & + & + \\
\hline & $8^{\circ} \mathrm{C}$ & - & - & - & - & - & - & - & - & - & $+/-$ & + & + & + & + \\
\hline & $15^{\circ} \mathrm{C}$ & - & - & - & - & $+/-$ & + & + & + & + & + & + & + & + & + \\
\hline & $20^{\circ} \mathrm{C}$ & - & + & ++ & ++ & ++ & ++ & ++ & ++ & ++ & ++ & ++ & ++ & ++ & ++ \\
\hline & $37^{\circ} \mathrm{C}$ & - & ++ & +++ & +++ & +++ & +++ & +++ & +++ & +++ & +++ & +++ & +++ & +++ & +++ \\
\hline & $41^{\circ} \mathrm{C}$ & - & - & - & - & - & - & - & - & - & - & - & - & - & - \\
\hline & $45^{\circ} \mathrm{C}$ & - & - & - & - & - & - & - & - & - & - & - & - & - & - \\
\hline \multirow{8}{*}{ Serratia spp. Agar } & $\mathbf{h}$ & 18 & 24 & 42 & 49 & 68 & 74 & 95 & 139 & 163 & 211 & 242 & 261 & 296 & 319 \\
\hline & $4{ }^{\circ} \mathrm{C}$ & - & - & - & - & - & - & - & - & - & - & - & - & $+/-$ & + \\
\hline & $8^{\circ} \mathrm{C}$ & - & - & - & - & - & - & - & - & - & - & - & $+/-$ & + & + \\
\hline & $15^{\circ} \mathrm{C}$ & - & - & - & - & - & - & $+/-$ & + & + & + & + & + & + & + \\
\hline & $20^{\circ} \mathrm{C}$ & - & - & + & ++ & ++ & ++ & ++ & ++ & ++ & ++ & ++ & ++ & ++ & ++ \\
\hline & $37^{\circ} \mathrm{C}$ & - & +++ & +++ & +++ & +++ & +++ & +++ & +++ & +++ & +++ & +++ & +++ & +++ & +++ \\
\hline & $41^{\circ} \mathrm{C}$ & - & - & - & - & - & - & - & - & - & - & - & - & - & - \\
\hline & $45^{\circ} \mathrm{C}$ & - & - & - & - & - & - & - & - & - & - & - & - & - & - \\
\hline
\end{tabular}

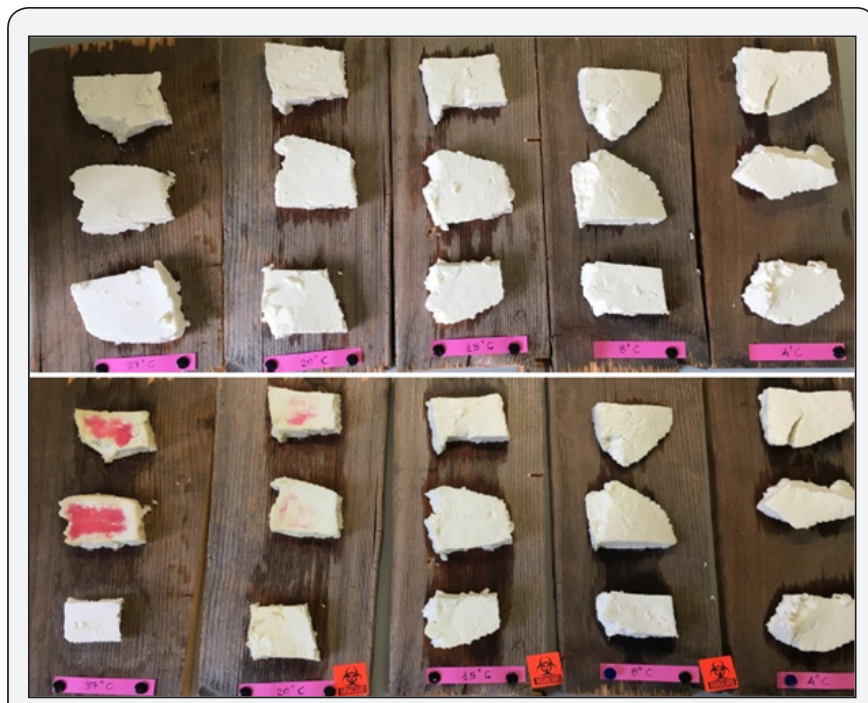

Figure 2 : Ability to grow at different temperatures of Serratia spp. on ricotta cheese
Finally the growth of the strain on ricotta samples was also recorded (Figure 2): differently from broth and medium, at 4, 8 and $15{ }^{\circ} \mathrm{C}$ no growth was recorded; this could be due to the slower growth rate of the microorganism at that temperatures (verified in broth and medium) combined with the different condition of maintenance of ricotta in the thermostats used for the simulation if compared to the seasoning cells present in the dairies. The product maintained in the lab thermostats was subjected to a faster dehydration, especially on the surface, where Serratia spp. was inoculated. At 20 and $37{ }^{\circ} \mathrm{C}$ the appearance of pink defect was evident and fast (within $24 \mathrm{~h}$ and 48 at 20 and $37{ }^{\circ} \mathrm{C}$ respectively). The defect appeared to be superficial, suggesting hypothesizing that when occurring during seasoning at the dairies, it is most likely due to the contact with utensils/ surfaces contaminated with the microorganism. At the moment of color defect appearance, water activity (aw) was equal to 0.951 and 0.941 in ricotta samples at 37 and $20^{\circ} \mathrm{C}$ respectively ( 0.945 at the beginning of the trial), while $\mathrm{pH}$ resulted to be 5.53 and5.59 at 20 and $37^{\circ} \mathrm{C}$, showing a strong decrease if compared 
to the $\mathrm{pH}$ recorded at $\mathrm{T} 0$ (6.33). Considering these results an evident acidification occurred probably due to the Lactic Acid Bacteria action. Generally it was demonstrated that Serratia spp. was easily able to grow during the first days of seasoning.

\section{Conclusion}

Serratia spp. was found to be responsible for pink discoloration of seasoned ricotta; only in the first environmental sampling session the microorganism was also isolated from facilities and utensils. During the other sampling sessions, Serratia spp. was never found. Interesting findings were also obtained regarding hygienically conditions of northern-alpine diaries. Salmonella spp. and VTEC were always absent and L. monocytogenes isolated just in two sampling point in one of the 9 diaries involved, probably its presence could be related to the traditional cheese making that include the use of wooden materials. The high and widespread presence of E. coli and Enterobacteriaceae point out the need of a stricter application of Good Manufacturing Practices in these little alpine dairies facilities in order to minimize the presence of spoilage and pathogenic bacteria, including those relevant for discoloration defects.

\section{Acknowledgement}

The authors would like to thank all the people working in the diaries involved in the survey.

\section{Conflict of Interest}

No conflict of interest is declared by authors.

\section{References}

1. Dioguardi L, Franzetti L, Sangiorgi F (2008) Environmental and surface hygienic quality of small dairies in mountain areas: Suggestion to improve food safety. In Proceedings of international conference "innovation technology to empower safety, health and welfare in agriculture and agro-food systems", Ragusa, Italy.

2. Dioguardi L, Franzetti L (2010) Influence of environmental conditions and building structure on food quality: A survey of hand-crafted dairies in Northern Italy. Food Control 21: 1187-1193.

3. Dufossé L (2009) Pigments, Microbial. In: Schaechter M (Ed.), Encyclopedia of microbiology, $3^{\text {rd }}$ (edn.), Academic Oxford.

4. Daly DFM, McSweeney PLH, Sheehan JJ (2012) Pink discolouration defect in commercial cheese: a review. Dairy Sci \& Technol 92(5): 439453
5. Asperger H (1986) Fermentiertemilchprodukte und einflüsse von hygienekeimen-2 Teil: Qualitätsfchler und verderben auf grundmikrobiellerursachen. Ernahrun/Nutrition 10: 227-232

6. Betzold N (2004) Pink discoloration of mozzarella cheese. Thesis, University of Wisconsin, Wisconsin

7. McSweeney PLH (2007) In: McSweeney PLH (Ed.), Cheese problems solved. Wood head, Cambridge

8. O'Connell JE, Fox PF (2001) Significance and applications of phenolic compounds in the production and quality of milk and dairy products: a review. Int Dairy J 11: 103-120.

9. Alberghini L, Tallone G, Giaccone V (2010) A new discoloration of ricotta cheese. AIVI giugno 8: 1-4.

10. Rudi K, Skulberg OM, Larsen F, Jacoksen KS (1997) Strain characterization and classification of oxyphotobacteria in clone cultures on the basis of $16 \mathrm{~S}$ rRNA sequences from variable regions V6,V7 and V8. Appl Environ Microb 63(7): 2593-2599.

11. Oliver SP, Jayarayo BM, Almeida RA (2005) Food borne Pathogens in Milk and the Dairy Farm Environment: Food Safety and Public Health Implications. Foodborne Pathogens and Disease 2(2): 115-129.

12. D’Amico DJ, Druart MJ, Donnelly CW (2010) Behavior of Escherichia coli 0157:H7 during the manufacture and aging of Gouda and stirred-curd Cheddar cheeses manufactured from raw milk. J Food Prot 73(12): 2217-2224.

13. Shrestha S, Grieder JA, McMahon DJ, Numme BA (2011) Survival of Listeria monocytogenes introduced as a post-aging contaminant during storage of low-salt Cheddar cheese at 4,10 , and $21^{\circ} \mathrm{C}$. J Dairy Sci 94(9): 4329-4335

14. Osaili TM, Al-Nabulsi AA, Olaimat AN, Shaker RR, Taha M, et al. (2014) Survival of Escherichia coli 0157:H7 during Manufacture and Storage of White Brined Cheese. Journal of Food Science 79(9): M1750-M1755.

15. Pradhan AK, Van Kessel JS, Karns JS, Wolfgang DR, Hovingh E, et al. (2009) Dynamics of endemic infectious diseases of animal and human importance on three dairy herds in the northeastern United States. J Dairy Sci 92(4): 1811-1825.

16. Latorre AA1, Van Kessel JA, Karns JS, Zurakowski MJ, Pradhan AK, et al. (2011) Increased in vitro adherence and on-farm persistence of predominant and persistent Listeria monocytogenes strains in the milking system. Applied and Environmental Microbiology 77(11): 3676-3684.

17. Melo J, Andrew PW, Faleiro ML (2015) Listeria monocytogenes in cheese and the dairy environment remains a food safety challenge: The role of stress responses. Food Research International 67: 75-90. 


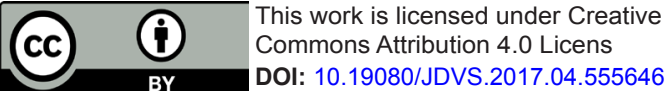

BY DOI: 10.19080/JDVS.2017.04.555646
Your next submission with Juniper Publishers will reach you the below assets

- Quality Editorial service

- Swift Peer Review

- Reprints availability

- E-prints Service

- Manuscript Podcast for convenient understanding

- Global attainment for your research

- Manuscript accessibility in different formats

( Pdf, E-pub, Full Text, Audio)

- Unceasing customer service

Track the below URL for one-step submission https://juniperpublishers.com/online-submission.php 